\title{
Effects of reduced intramammary antimicrobial use during the dry period on udder health in Dutch dairy herds
}

\author{
A. Vanhoudt, ${ }^{* 1}$ K. van Hees-Huijps,† A. T. M. van Knegsel,† O. C. Sampimon,§ J. C. M. Vernooij, ${ }^{*}$ M. Nielen, ${ }^{*}$ \\ and T. van Werven*\# \\ *Department of Farm Animal Health, Faculty of Veterinary Medicine, Utrecht University, $3584 \mathrm{CL}$, Utrecht, the Netherlands \\ tkirstenvanhees.nl, $5451 \mathrm{NR}$, Mill, the Netherlands \\ $\ddagger$ Adaptation Physiology Group, Department of Animal Sciences, Wageningen University and Research, PO Box 338, $6700 \mathrm{AH}$, Wageningen, \\ the Netherlands \\ §Zoetis B.V., 2909 LD, Capelle a/d IJssel, the Netherlands \\ \#University Farm Animal Practice, 3481 LZ, Harmelen, the Netherlands
}

\section{ABSTRACT}

Dry cow therapy (DCT) in the Netherlands changed from mainly blanket to selective antimicrobial DCT. This transition was supported by a national guideline, with the individual somatic cell count (SCC) at the last milk recording before dry-off as the main selection criterion for antimicrobial DCT. The aim of this retrospective observational study is to evaluate the SCC dynamics during the dry period at the herd and individual dry period level following the national transition from mainly blanket to selective antimicrobial DCT. At the herd level, we used 2 data sets to evaluate the SCC dynamics during the dry period: (1) a national data set containing 3,493 herds with data available from 2011 through 2015 and (2) a veterinary practice data set containing 280 herds with data available from 2013 through 2015. The herd level analysis was carried out using key performance indicators provided via milk recording (CRV, Arnhem, the Netherlands): the percentage of cows that developed a new intramammary infection (IMI) during the dry period and the percentage of cows cured of an IMI during the dry period. The effect of DCT at individual dry period level was analyzed with a mixed-effects logistic regression model based on 4,404 dry periods from 2,638 cows in 20 herds within the veterinary practice data set. For these 20 herds, individual SCC data from milk recordings and individual cow DCT were available from 2013 through 2015. No significant changes were observed to the SCC dynamics during the dry period at the herd level. The percentage of cows that developed a new IMI during the dry period ranged between 16 and $18 \%$, and the percentage of cows cured from an IMI during the dry

Received July 24, 2017.

Accepted November 28, 2017.

${ }^{1}$ Corresponding author: a.vanhoudt@uu.nl period ranged between 74 and $76 \%$. At the individual dry period level, a low SCC at the first milk recording following a dry period was associated with the use of intramammary antimicrobial DCT with or without the concurrent use of an intramammary teat sealer [odds ratio $(\mathrm{OR})=2.16$ and $\mathrm{OR}=2.07$, respectively], the use of DCT with an intramammary teat sealer only $(\mathrm{OR}=$ 1.35), and a low SCC at the last milk recording before dry-off $(\mathrm{OR}=1.78)$. This study demonstrates that the selection of cows for DCT without antimicrobials based on SCC thresholds at the last milk recording is possible without significant changes to udder health and reduced the use of antimicrobials.

Key words: antimicrobial, dairy cow, dry period, selective dry cow therapy, udder health

\section{INTRODUCTION}

Udder health management is important in the maintenance of a healthy and profitable dairy herd (Middleton et al., 2014). Dry cow therapy (DCT) with intramammary antimicrobials has long been recommended as an essential part of udder health management on dairy farms (Dodd et al., 1969). The goal of DCT is to treat any existing IMI at dry-off and to prevent the occurrence of a new IMI during the dry period. For this reason, the advice has been to treat all cows with an intramammary antimicrobial at dry-off, irrespective of the presence or absence of an IMI (blanket dry cow therapy, BDCT; Dodd et al., 1969; Eberhart, 1986; Dingwell et al., 2003). In contrast, many Nordic countries have refrained from using BDCT and have been successfully using selective dry cow therapy (SDCT) since the 1970s or earlier (Osteras et al., 1999; Ekman and Osteras, 2003; Osteras and Solverod, 2009). With SDCT, only those cows most likely to have an IMI at dry-off are treated with intramammary antimicrobials. Several cow level variables such as SCC, bacteriologi- 
cal culture, and clinical mastitis history are considered when selecting cows likely to have an IMI at dry-off (Torres et al., 2008; Cameron et al., 2015; Kiesner et al., 2016).

To reduce the development of antimicrobial resistance, there has been an increasing worldwide interest in the prudent use of antimicrobials and in a reduction in the use of antimicrobials in general (WHO, 2015; OIE, 2016; Goff et al., 2017). Since 2008, the Dutch government, together with livestock and veterinary associations, has taken a proactive role in the reduction of antimicrobial use in livestock species (Speksnijder et al., 2015). As a result, there has been a mandatory reduction in the use of antimicrobials in Dutch livestock: $20 \%$ by $2011,50 \%$ by 2013 , and $70 \%$ by 2015 in relation to their use in 2009. One way these drastic reductions were achieved is the ban, in effect since November 2012, on the preventive use of antimicrobials in Dutch livestock. As a result, Dutch dairy farmers have been forced to use SDCT rather than BDCT. In January 2014, the Royal Dutch Veterinary Association provided a guideline, "The use of antimicrobials at dryoff in dairy cattle," to support veterinarians in advising dairy farmers in the practice of SDCT (KNMvD, 2014). Individual SCC from a composite milk sample taken at the last milk recording before dry-off became the main selection criterion for the use of antimicrobials at dry-off (see Appendix for details). The SCC thresholds used in the guideline were based on the results of a deterministic modeling study by Scherpenzeel et al. (2016a) and were expected to result in an optimal tradeoff between reduced use of antimicrobials associated with udder health (DCT and mastitis therapy) versus minimal increased risk of new IMI after the dry period.

Legitimate concerns have been raised by farmers and veterinarians about the negative effect of the potential increase in both clinical and subclinical mastitis associated with SDCT and its consequential effect on animal welfare and production. Therefore, the aim of this study is to evaluate the SCC dynamics during the dry period at herd and individual dry period level following the aforementioned national transition from mainly BDCT to SDCT in the Netherlands. Furthermore, this study describes the reduction in the use of antimicrobials associated with udder health during the transition from BDCT to SDCT. We used a multilevel approach, applying a gradually more detailed analysis. First, we analyzed herd level SCC information before and after the dry period in a national data set. Second, we analyzed the sales figures of intramammary products and herd level SCC information before and after the dry period in a data set from a single veterinary practice. Third, we analyzed herd level SCC information before and after the dry period and most importantly individual DCT and associated individual SCC before and after the dry period in a subset of the veterinary practice data set.

\section{MATERIALS AND METHODS}

\section{Antimicrobial Use Associated with Udder Health}

Veterinary Practice Level. The University Farm Animal Practice serves around 330 dairy cattle herds, comprising about 27,500 cows in total. All antimicrobial drugs used on these herds were distributed solely by the veterinary practice. We extracted the number of total annual sales of intramammary products (dry cow antimicrobials, mastitis antimicrobials, and teat sealers) to these herds from the practice's management software system (Viva 1.0, Corilus Veterinary BV, Houten, the Netherlands).

Herd Level. We calculated the mean animal-defined daily dose (DDDA) for overall antimicrobial and intramammary antimicrobials (DCT and mastitis therapy) use from 2013 through 2015 for a subset of 20 herds. These 20 herds were a convenience sample based on the availability of data for the analysis of individual DCT and the associated SCC dynamics during the dry period. No other selection criteria were applied. To calculate the DDDA, we followed standard operating procedures of the Netherlands Veterinary Medicines Authority as described by Gonggrijp et al. (2016).

\section{SCC Dynamics During the Dry Period}

We used an elevated SCC as an indicator for the presence of an IMI (Schukken et al., 2003; Vissio et al., 2014). In line with the thresholds for elevated SCC used in Dutch national milk recording, primiparous cows with an SCC $\geq 150,000$ cells/mL and multiparous cows with an SCC $\geq 250,000$ cells/mL were classified as infected (de Haas et al., 2008). In this study, we investigated dry period SCC dynamics using key performance indicators provided via milk recording (CRV, Arnhem, the Netherlands). The key performance indicators used were the mean percentage of cows with a new IMI at the first milk recording following a dry period (percent new IMI) and the mean percentage of cows cured of an IMI during the dry period (percent cured IMI). A new IMI was defined as a change in SCC from below the threshold at the last milk recording before calving to an SCC equal to or greater than the threshold at the first milk recording after calving. A cured IMI was defined as a change in SCC from equal to or greater than the threshold at the last milk recording before calving to an SCC below the threshold at the first milk recording after calving. 
We initially analyzed the SCC dynamics during the dry period at herd level. However, results from a statistical analysis at the group level do not necessarily also hold true for the individuals that make up the group. This form of epidemiological bias is referred to as an ecological fallacy (Sedgwick, 2015). To avoid this ecological fallacy, we also analyzed data associated with the dry period SCC dynamics at the individual dry period level.

National Data Set-Herd Level Analysis. We randomly selected a sample of 3,493 Dutch dairy herds with $\geq 70$ cows and participating in milk recording $(\mathrm{CRV})$. No other selection criteria were applied. The frequency of milk recording in these herds varied from every 4 to every 6 wk. The monthly percent new IMI and percent cured IMI of milk recordings from 2011 through 2015 from each herd were available for analysis. These data were used to calculate the mean percent new IMI and the mean percent cured IMI over all of the 3,493 herds for each year. Cows had to be at least 5 DIM at their first milk recording.

Veterinary Practice Data Set-Herd Level Analysis. The annual mean percent new IMI and the annual mean percent cured IMI from milk recordings (CRV) were available from 2013 through 2015 for 280 dairy herds served by the University Farm Animal Practice (Harmelen, the Netherlands). For each year, we calculated the annual mean percent new IMI and the annual mean percent cured IMI by combining the data from all 280 herds. We also calculated these variables for a subset of 20 herds with individual cow DCT data available via farm management software (CowVision, AgroVision, Deventer, the Netherlands). This subset is the same subset as used for the herd level analysis of antimicrobial use associated with udder health. No other selection criteria were applied.

Veterinary Practice Data Set-Dry Period Level Analysis. To study the relationship between the SCC dynamics during the dry period and individual cow DCT, we used the same subset of 20 herds as we did for the herd level analyses. For these 20 herds, individual SCC data from milk recordings and individual cow DCT were available from 2013 through 2015. Only cows with an SCC for both the last milk recording before dry-off (LSCC) and the first milk recording following a dry period (FSCC) were used for analysis. The LSCC had to have been recorded within 6 wk before dry-off and the FSCC not earlier than $5 \mathrm{~d}$ after calving. No other selection criteria were applied.

\section{Statistical Analyses}

Data were first extracted from the different software programs and exported to MS Excel (Microsoft Office,
Redmond, WA) for initial data handling. Summary statistical analyses were performed using SPSS 24.0.0.1 (IBM, New York, NY).

To investigate the effect of individual cow DCT at dry period level, we used a mixed-effects logistic regression model (Bates et al., 2015) with FSCC as the dependent variable $(0=$ greater than or equal to the threshold, 1 = less than the threshold). The FSCC threshold was set at an SCC of 150,000 cells/mL for cows that were primiparous before the dry period and at an SCC of 250,000 cells $/ \mathrm{mL}$ for all other cows (de Haas et al., 2008). Independent variables tested in the full multivariable model were DCT (no DCT, intramammary teat sealer and antimicrobial DCT, intramammary antimicrobial DCT only or intramammary teat sealer only), LSCC ( $<$ the threshold or $\geq$ the threshold; the same thresholds were used as for FSCC), type of milking system (automatic or conventional), dry period length $(\leq 30 \mathrm{~d}, 31-60 \mathrm{~d}$, or $>60$ d), parity at the moment of LSCC (primiparous or multiparous), and year of dry-off (2013, 2014, or 2015). Herd was used as a random effect to take the correlation between observations within a herd into account. The effect of repeated observations at individual cow level could not be included because approximately half the cows only had a single dry period during the study period. The year of dry-off was fixed in the model as this study aimed to evaluate the change in dry period SCC dynamics over time. The final reduced model was based on the lowest Akaike information criterion using a backward elimination approach. The mixed-effects logistic regression model analysis was applied in $\mathrm{R}$ version 3.3.0 (R Core Team, 2016).

\section{RESULTS}

\section{Antimicrobial Use Associated with Udder Health}

Veterinary Practice Level. From 2013 through 2015 , the total sales figures for intramammary dry cow and mastitis antimicrobials decreased by 38 and $19 \%$, respectively, whereas the total sales figures of intramammary teat sealers increased by $73 \%$ (Table 1 ).

Herd Level. The overall use of antimicrobials (DDDA) in the 20 herds in the subset decreased by $29 \%$ in 2015 compared with 2013. During the same period, the use of intramammary dry cow antimicrobials decreased by $35 \%$ and the use of intramammary mastitis antimicrobials decreased by $29 \%$ (Table 1). Overall, the median percentage of dry periods during which intramammary antimicrobial DCT was applied on these 20 herds decreased from $64 \%$ [mean $64 \%$; interquartile range (IQR) 49-84\%] in 2013 to $55 \%$ (mean 50\%; IQR $26-74 \%$ ) in 2014 , and to $52 \%$ (mean $51 \%$; IQR $36-74 \%$ ) 


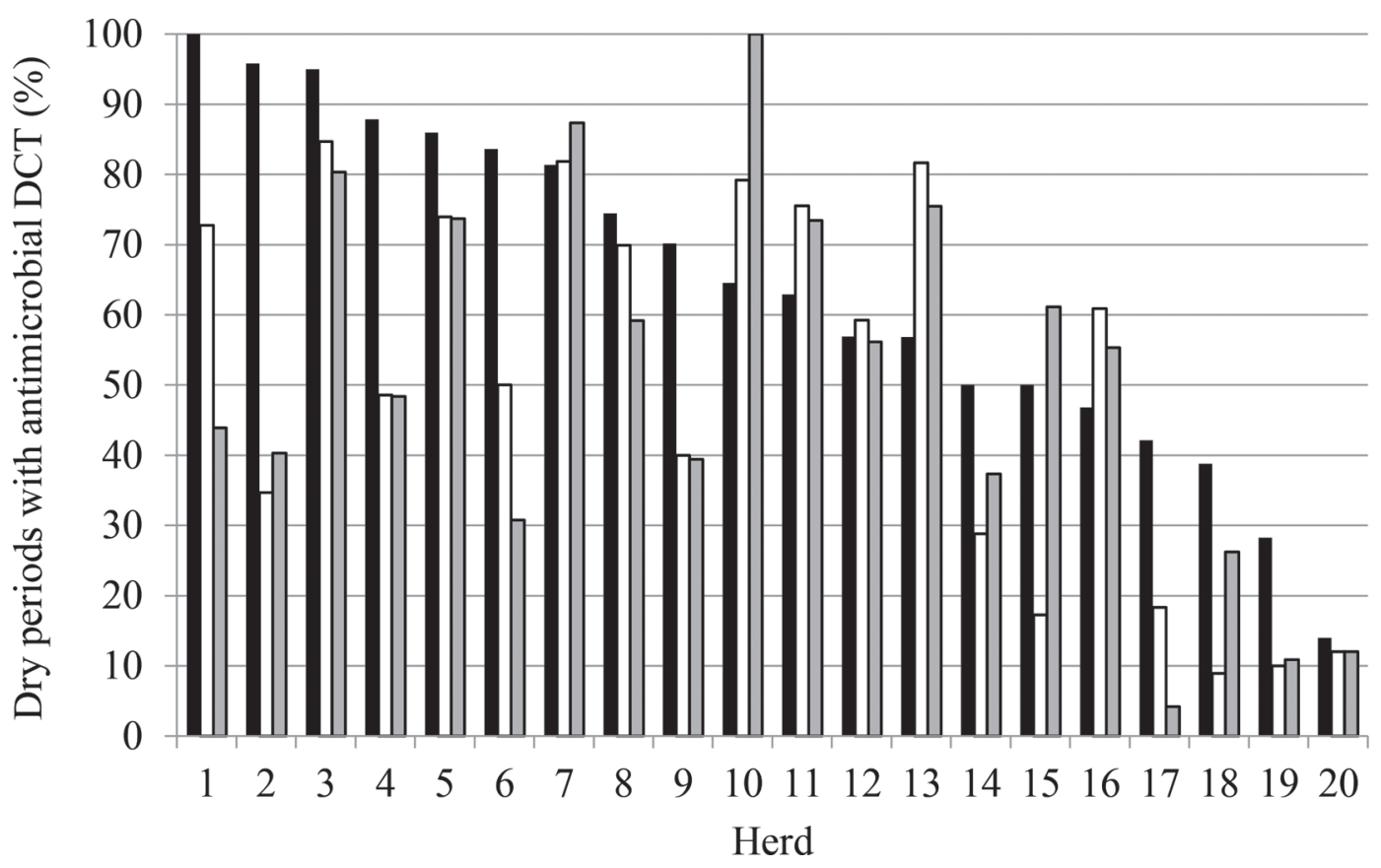

Figure 1. The annual mean percentage of dry periods with use of intramammary antimicrobial dry cow therapy (DCT) in 20 herds served by a single veterinary practice in the Netherlands (2013, black bars; 2014, white bars; and 2015, gray bars).

in 2015. More detail on the use of intramammary antimicrobial DCT per year on these 20 herds during the study period is presented in Figure 1.

\section{SCC Dynamics During the Dry Period}

National Data Set-Herd Level Analysis. The annual mean percent new IMI remained at $16 \%$ from 2011 through 2013. In 2014, it increased to $18 \%$, to decline again to $17 \%$ in 2015 . We found little variation in the annual mean percent cured IMI, being $74 \%$ from
2011 through 2014 and increasing to $75 \%$ in 2015 . We did, however, identify seasonal trends, with the highest mean percent new IMI and the lowest mean percent cured IMI occurring during the summer months in each year (Figures 2 and 3 ).

Veterinary Practice Data Set-Herd Level Analysis. The annual mean percent new IMI changed from $16 \%$ in 2013 to $18 \%$ in 2014 , and to $17 \%$ in 2015 , whereas the annual mean percent cured IMI was $74 \%$ in 2013 and 2014, and $76 \%$ in 2015 on the 280 herds in the veterinary practice data set (Table 1 ). The annual

Table 1. Overview of annual variables associated with udder health from 2013 through 2015 in herds serviced by a single veterinary practice in the Netherlands

\begin{tabular}{|c|c|c|c|c|}
\hline Level of analysis & Variable & \multicolumn{3}{|c|}{ Year } \\
\hline$(\mathrm{n}= \pm 330$ herds $)$ & Mastitis antimicrobials, tubes & 36,000 & 29,000 & 29,000 \\
\hline & Teat sealers, tubes & 15,000 & 21,000 & 26,000 \\
\hline Mean animal-defined daily dose $(\mathrm{n}=20$ herds) & Antimicrobials in general & 3.4 & 2.4 & 2.4 \\
\hline \multirow{3}{*}{$\begin{array}{l}\text { SCC dynamics during the dry period } \\
\text { Herd level }(\mathrm{n}=280 \text { herds })\end{array}$} & & & & \\
\hline & Mean (SD) \% new IMI & $16(9)$ & $18(10)$ & $17(9)$ \\
\hline & Mean (SD) \% cured IMI & $74(16)$ & $74(18)$ & $76(17)$ \\
\hline \multirow[t]{2}{*}{ Herd level ( $\mathrm{n}=20$ herds) } & Mean (SD) \% new IMI & $12(9)$ & $16(6)$ & $14(8)$ \\
\hline & Mean (SD) \% cured IMI & $83(12)$ & $79(12)$ & $80(11)$ \\
\hline
\end{tabular}

${ }^{1}$ Rounded off to the nearest thousand. 


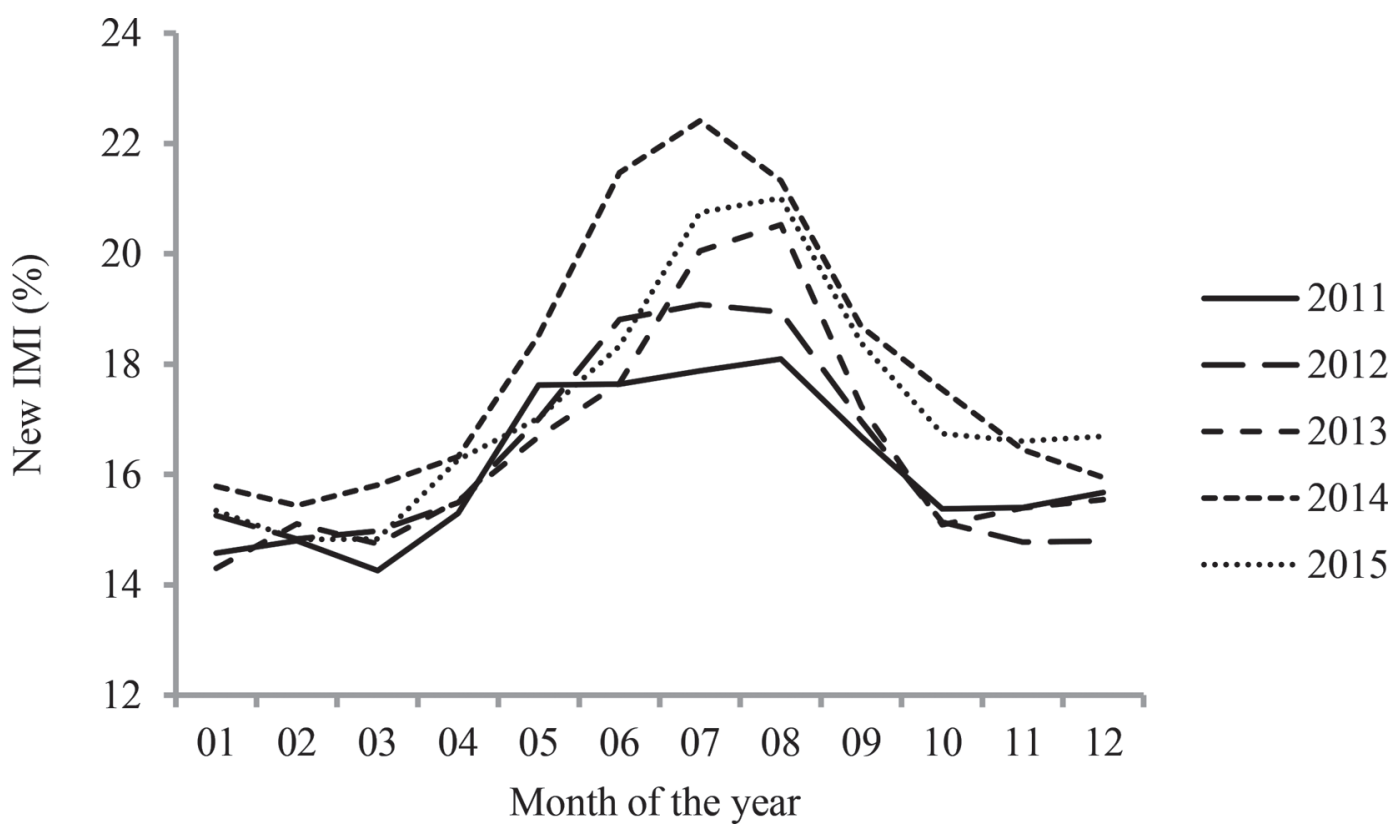

Figure 2. Mean herd level percentage of cows with a new infection at the first milk recording following a dry period (\% new IMI) as a monthly distribution per year in 3,493 Dutch dairy herds.

mean percent new IMI and annual mean percent cured IMI after the dry period in the subset of 20 herds followed the same trend as in the 280 herds and the herds in the national data set. The annual mean percent new IMI changed from $12 \%$ in 2013 to $16 \%$ in 2014 , and to $14 \%$ in 2015 . The annual mean percent cured IMI changed from $83 \%$ in 2013 to $79 \%$ in 2014 , and to $80 \%$ in 2015.

Veterinary Practice Data Set-Dry Period Level Analysis. Herd size of the 20 farms in the subset varied between 51 and 288 lactating cows, and the 305-d milk production level ranged from 7,411 to

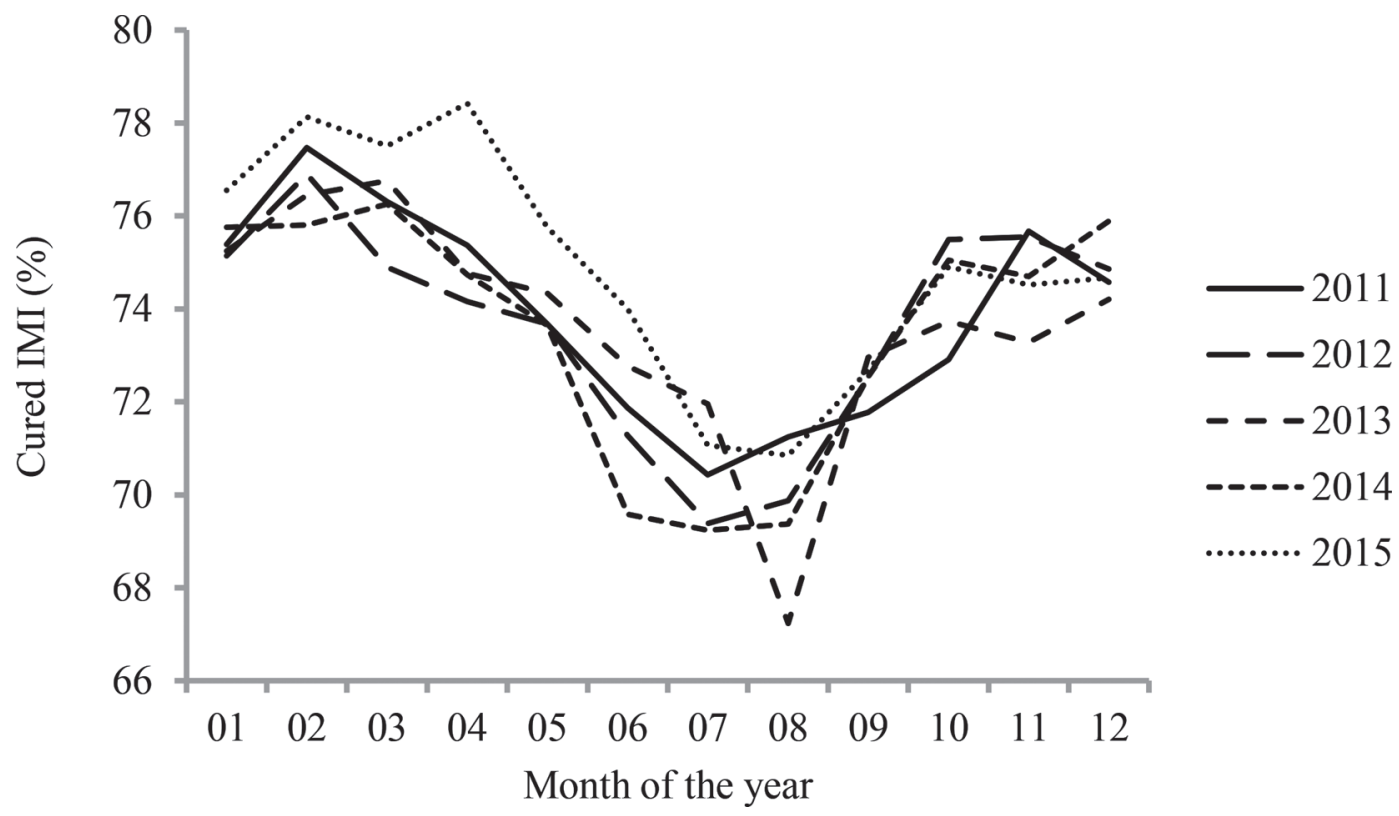

Figure 3. Mean herd level percentage of cows that were infected at the start of their dry period and that had been cured of this infection by the first milk recording after calving (\% cured IMI) as a monthly distribution per year in 3,493 Dutch dairy herds. 
Table 2. Results of the final reduced mixed-effects logistic regression model ${ }^{1}$ of the dry period SCC dynamics at the individual dry period level with the SCC of the first milk recording following a dry period as the dependent variable $\left(0=\right.$ greater than or equal to the threshold, ${ }^{2} 1=$ less than the threshold $;{ }^{2} \mathrm{n}=20$ herds, 4,404 dry periods, and 2,638 cows)

\begin{tabular}{|c|c|c|c|}
\hline Variable & Odds ratio & \multicolumn{2}{|c|}{$95 \% \mathrm{CI}$} \\
\hline \multicolumn{4}{|l|}{ Intramammary dry cow therapy (DCT) } \\
\hline No DCT & Referent & - & - \\
\hline Teat sealer only & 1.35 & 1.00 & 1.81 \\
\hline Antimicrobial DCT only & 2.07 & 1.62 & 2.63 \\
\hline Teat sealer and antimicrobial DCT & 2.16 & 1.51 & 3.08 \\
\hline \multicolumn{4}{|c|}{ SCC of the last milk recording before dry-off } \\
\hline$\geq$ the threshold $^{2}$ & Referent & - & - \\
\hline$<$ the threshold ${ }^{2}$ & 1.78 & 1.45 & 2.17 \\
\hline \multicolumn{4}{|l|}{ Year of dry-off ${ }^{3}$} \\
\hline 2013 & Referent & - & - \\
\hline 2014 & 0.83 & 0.67 & 1.03 \\
\hline 2015 & 0.95 & 0.76 & 1.19 \\
\hline
\end{tabular}

${ }^{1}$ Herd was used as a random effect to take the correlation between observations within a herd into account.

${ }^{2}$ The SCC threshold was $\geq 150,000$ cells $/ \mathrm{mL}$ for primiparous cows and $\geq 250,000$ cells $/ \mathrm{mL}$ for multiparous cows.

${ }^{3}$ The year of dry-off was fixed in the model because this study aimed to evaluate the change in dry period SCC dynamics over time.

10,474 kg of milk. On 8 farms, cows were milked using an automatic milking system: 1 of these farms only started using the automated milking system in 2015. Dry cows had access to pasture on 4 farms, indicating that the majority of farms kept their dry cows inside. Dry cow housing consisted of green bedding (2 farms), a straw yard (1 farm), or cubicles with mats or mattresses and chopped straw (17 farms). One of the farms was organic. The annual mean culling rates of cows that had calved at least once were $25 \%$ (SD 7) in 2013, $26 \%$ (SD 7) in 2014, and 25\% (SD 8) in 2015.

The initial data set from the 20 herds used for the mixed-effects logistic regression model analysis at individual dry period level contained 2,880 cows and 4,962 dry periods. Selection for the presence of an FSCC resulted in 2,733 cows and 4,695 dry periods. Selection for those dry periods associated with an LSCC that was recorded within 6 wk before dry-off resulted in 4,404 dry periods from 2,638 cows ( 1,412 dry periods from primiparous cows and 2,992 dry periods from multiparous cows) that were available for further analysis. Over the 3-yr study period, around 1,400 to 1,500 dry periods per year were analyzed with a mean dry period length of $51 \mathrm{~d}$ (SD 18, range: 1 to $232 \mathrm{~d}$ ). The mean dry period length varied between 50 and 52 d over the 3 yr. During the study period, 1,294 cows had 1 dry period, 923 cows had 2 dry periods, 420 cows had 3 dry periods, and 1 cow had 4 dry periods. The mean DIM at FSCC was $23 \mathrm{~d}$ (SD 12, range: 5 to $97 \mathrm{~d}$ ).

The mixed-effects logistic regression model, used to evaluate variables related to the SCC dynamics at individual dry period level, indicated that DCT and LSCC were related to FSCC. Low FSCC was associated with the use of intramammary antimicrobial DCT with or without concurrent use of an intramammary teat sealer [odds ratio $(\mathbf{O R})=2.16$ and $\mathrm{OR}=2.07$, respectively], the use of DCT with an intramammary teat sealer only $(\mathrm{OR}=1.35)$, and a low LSCC $(\mathrm{OR}=1.78)$. Year of dry-off was fixed in the model and had a lower odds on low FSCC in year $2014(\mathrm{OR}=0.83)$ and $2015(\mathrm{OR}=$ 0.95) compared with 2013, with overlapping $95 \%$ confidence intervals (Table 2).

\section{DISCUSSION}

\section{Antimicrobial Use Associated with Udder Health}

A remarkable reduction occurred in the number of antimicrobials used, both at the veterinary practice level and in the subset of 20 herds. The DDDA reduction percentages in the 20 herds were similar to or higher than those achieved at the national level as reported by the Netherlands Veterinary Medicines Authority (SDa, $2014,2015,2016)$. It is therefore likely that, on average, a similar reduction in antimicrobial use took place in the herds in the national data set, although we were unable to measure this. The mean percent new IMI and mean percent cured IMI during the dry period had changed little or had shown only a slight improvement by 2015 , despite the decreased use of antimicrobials in general and intramammary antimicrobials (DCT and mastitis therapy), in particular on the dairy herds in this study. One possible explanation could be that with the shift from mainly BDCT to SDCT, both dairy farmers and veterinarians adjusted their focus to other management practices, such as hygiene and transition cow management, to ensure optimal udder health in their herds (Green et al., 2007, Scherpenzeel et al., 
2016b). Unfortunately, this study did not include a questionnaire to monitor changes in the management practices on the herds studied. This information would have enabled a more in-depth discussion of the possible reasons why udder health remained stable in the herds investigated in this study. Potentially, the excessive culling of cows with poor udder health could explain why the mean percent new IMI and mean percent cured IMI during the dry period did not show a deterioration in this study. In the 20 herds in the subset, excessive culling did not take place, as the overall annual mean culling rates of cows that had calved at least once remained stable during the study period. It is, however, possible that farmers changed their culling priority and reduced the number of lame cows culled, for example, and increased the number of cows with poor udder health culled, thus resulting in similar annual mean culling rates. Unfortunately, such detailed information is not available. Finally, all the veterinary practice data originated from a single veterinary practice (with 13 veterinarians) that is part of Utrecht University. This may have caused a bias in the type of herds used for this study and the advice on udder health management practices on these herds. This bias is likely to be small, however, as there was only a minor difference in the dry period SCC dynamics results from the national and veterinary practice data sets and both data sets contained a reasonable number of herds.

Throughout 2013, intramammary antimicrobial DCT was applied to a median of $64 \%$ of the dry periods on the 20 herds with individual animal dry period level data available. This is similar to the results obtained by Scherpenzeel et al. (2016b) who found that in the 133 Dutch herds in their study that applied SDCT in 2013, a median of $67 \%$ of cows were dried off using antimicrobial DCT. Substantial variation was present between herds in the percentage of dry periods during which intramammary antimicrobial DCT was applied. Indeed, the coefficient of variation was high, ranging from 0.36 in 2013 to 0.52 in 2014, and 0.51 in 2015 . In 6 of the 20 herds in the subset, the percentage of cows dried off with intramammary antimicrobial DCT increased following the introduction of the guideline on the use of antimicrobials at dry-off in January 2014. The mean LSCC of animals that were dried off without intramammary antimicrobial DCT in 2015 was lower than in 2013 in 4 of these 6 herds (results not shown). This implies that the farmers on these herds had become less selective in their use of intramammary antimicrobial DCT at dry-off in 2015 as compared with 2013. Unfortunately, no other information was available to help explain the causes for the increased use of intramammary antimicrobial DCT in these 6 herds.

\section{SCC Dynamics During the Dry Period}

In this retrospective observational study in the Netherlands, we evaluated the effect of a nationwide transition from mainly BDCT to SDCT on SCC dynamics during the dry period. To the best knowledge of the authors, this observational study is the first to investigate the effect of a national transition from mainly BDCT to SDCT on dry period SCC dynamics using both population data and individual animal DCT data. All analyses in this study indicated that the transition from mainly BDCT to SDCT in the Netherlands was, on average, associated with no significant changes to udder health across the dry period and with a decrease in antimicrobial use. By applying SDCT, only those cows with a higher risk of an IMI at dry-off are targeted with intramammary antimicrobial DCT. A commonly used threshold for the presence of an IMI is an SCC $\geq 200,000$ cells/mL (Schukken et al., 2003; Vissio et al., 2014). The recommended thresholds for intramammary antimicrobial DCT described in the guideline on the use of antimicrobials at dry-off in dairy cattle in the Netherlands are below this level at 150,000 cells/mL (primiparous cows) and 50,000 cells/mL (multiparous cows; see Appendix for details). These thresholds ensure that all cows likely to have an IMI at dry-off still received intramammary antimicrobial DCT, as they would have in herds that apply BDCT. On the other hand, these thresholds also ensure that only those cows with a very low to low LSCC, and therefore with a low risk of an existing IMI at dry-off, are dried off without intramammary antimicrobial DCT.

Following the introduction of the guideline on the use of antimicrobials in dairy cattle at dry-off in the beginning of 2014, all farmers in the Netherlands were forced to apply SDCT using the same selection criteria. This adaptation to new dry cow management and selection thresholds in 2014 might have contributed to the slightly less positive results in 2014 for the annual mean percent of new IMI and the annual mean percent of cured IMI when compared with data from 2013.

The results for the annual mean percent of new IMI and the annual mean percent of cured IMI from the subset of 20 herds were better than those from the national and veterinary practice data sets. For these 20 herds, individual dry period level information was available via farm management software. Therefore, it is likely that a more conscientious type of farmer was selected, which could have biased the results in this study. On the other hand, it should be noted that it is possible that farmers did not enter all data relating to DCT correctly in the farm management software system. 
The monthly distributions of the mean herd level percent new IMI and percent cured IMI from the national data set were respectively highest and lowest during the summer. This finding is in line with the typical summer rise found for bulk milk SCC in herds living in a climate comparable to that in the Netherlands (Green et al., 2006; Olde Riekerink et al., 2007). Unfortunately, we could neither investigate whether the seasonal effect found in our study could be explained by an increase in the proportion of cows with a chronic or new IMI, nor which pathogens were involved.

The results from the mixed-effects logistic regression model could have been biased by the repeated effects of cows with multiple dry periods during the study. However, the overall tendency and median estimates of the variables that were retained in the final reduced model remained very stable in a bootstrapped approach (see Appendix). The final reduced model indicated that SDCT with intramammary antimicrobials, irrespective of the use of an intramammary teat sealer, doubled the odds of a low FSCC at the start of the lactation. Together with the absence of significant changes in the herd level mean percent new IMI and mean percent cured IMI analyzed in this study, we interpret this to indicate that the correct animals were selected for a dry period without intramammary antimicrobial DCT. The use of an intramammary teat sealer at dry-off also increased the odds of a low FSCC, but mostly in combination with intramammary antimicrobial DCT. Closure of the teat end with a keratin plug is important in preventing the udder from developing an IMI (Comalli et al., 1984). Nonetheless, work by Dingwell et al. (2004) found that successful closure of the teat end with a keratin plug only occurred in $77 \%$ of the quarters after 6 wk dry. Several studies have looked at the effect of using intramammary teat sealers on the risk of developing an IMI during the dry period and found their use to be protective (Berry and Hillerton, 2002; Mutze et al., 2012; Kromker et al., 2014). This study found that entering a dry period with a low LSCC increased the odds of a low FSCC. This is in line with findings by Green et al. (2007), who associated a high SCC at the last milk recording before dry-off with an increased rate of clinical mastitis during the first $30 \mathrm{~d}$ of the following lactation. Dry period length had no significant effect on the odds of having a low FSCC on the 20 herds that contributed data to the mixed-effects logistic regression model. This supports the work by van Hoeij et al. (2016) who found that dry period length is not a risk factor for a high FSCC nor for the occurrence of clinical mastitis in the subsequent lactation.

Following a period in which BDCT was an essential part of the of dry period management, the results from this study indicate that in the Netherlands a nationwide shift to SDCT over a relatively short period of time was associated with no significant changes to udder health during the dry period and with the decreased use of antimicrobials. The implementation of a national guideline on the use of antimicrobials in dairy cows at dry-off is likely to have helped in the selection of those cows that did not need antimicrobial DCT for a successful dry period, thus contributing to a more prudent use of antimicrobials and lowering the antimicrobial selection pressure.

\section{CONCLUSIONS}

The transition from mainly BDCT to SDCT in the Netherlands resulted in a reduction in the number of antimicrobials used on dairy herds without having a deleterious effect on udder health during the dry period. In the 20 herds that contributed to the individual dry period level analysis, this result was possible without extra culling. This study adds to the body of evidence that overall, and when managed appropriately at the cow and herd level, animals with a low risk of developing an IMI during the dry period can be successfully dried off without the use of intramammary antimicrobials.

\section{ACKNOWLEDGMENTS}

Preliminary results from this study were presented at the 6th IDF International Mastitis Conference (2016, Nantes, France) by T. van Werven and at the European Veterinary Conference (Voorjaarsdagen, 2017, The Hague, the Netherlands) by A. Vanhoudt. The authors thank the experts on the Boehringer Ingelheim udder health panel for their constructive criticism, CRV (Arnhem, the Netherlands) for providing the national dataset, I. M. van Geijlswijk (Netherlands Veterinary Medicines Authority and Pharmacy Department, Faculty of Veterinary Medicine, Utrecht University) for her advice concerning animal-defined daily dose, and J. Pocock (Write It Right, The Hague, the Netherlands) for editing and correction of the English in the manuscript. K. van Hees-Huijps was formerly employed by CRV (Arnhem, the Netherlands).

\section{REFERENCES}

Bates, D., M. Maechler, B. Bolker, and S. Walker. 2015. Fitting linear mixed-effects models using lme4. J. Stat. Softw. 67:1-48. https:// doi.org/10.18637/jss.v067.i01.

Berry, E. A., and J. E. Hillerton. 2002. The effect of an intramammary teat seal on new intramammary infections. J. Dairy Sci. 85:25122520. https://doi.org/10.3168/jds.S0022-0302(02)74334-8.

Cameron, M., G. P. Keefe, J. P. Roy, H. Stryhn, I. R. Dohoo, and S. L. McKenna. 2015. Evaluation of selective dry cow treatment following on-farm culture: Milk yield and somatic cell count in the 
subsequent lactation. J. Dairy Sci. 98:2427-2436. https://doi.org/ $10.3168 /$ jds.2014-8876.

Comalli, M. P., R. J. Eberhart, L. C. Griel Jr., and H. Rothenbacher. 1984. Changes in the microscopic anatomy of the bovine teat canal during mammary involution. Am. J. Vet. Res. 45:2236-2242.

de Haas, Y., W. Ouweltjes, J. ten Napel, J. J. Windig, and G. de Jong. 2008. Alternative somatic cell count traits as mastitis indicators for genetic selection. J. Dairy Sci. 91:2501-2511. https://doi.org/ $10.3168 /$ jds.2007-0459.

Dingwell, R. T., D. F. Kelton, and K. E. Leslie. 2003. Management of the dry cow in control of peripartum disease and mastitis. Vet. Clin. North Am. Food Anim. Pract. 19:235-265. https://doi.org/ 10.1016/S0749-0720(02)00072-5.

Dingwell, R. T., K. E. Leslie, Y. H. Schukken, J. M. Sargeant, L. L. Timms, T. F. Duffield, G. P. Keefe, D. F. Kelton, K. D. Lissemore, and J. Conklin. 2004. Association of cow and quarter-level factors at drying-off with new intramammary infections during the dry period. Prev. Vet. Med. 63:75-89. https://doi.org/10.1016/j .prevetmed.2004.01.012.

Dodd, F. H., D. R. Westgarth, F. K. Neave, and R. G. Kingwill. 1969 Mastitis-The strategy of control. J. Dairy Sci. 52:689-695. https:// doi.org/10.3168/jds.S0022-0302(69)86631-2.

Eberhart, R. J. 1986. Management of dry cows to reduce mastitis. J. Dairy Sci. 69:1721-1732. https://doi.org/10.3168/jds.S0022 -0302(86)80591-4.

Ekman, T., and O. Osteras. 2003. Mastitis control and dry cow therapy in the Nordic countries. Pages 18-30 in Natl. Mastitis Counc. Ann. Mtg. Proc., Fort Worth, TX. Natl. Mastitis Counc. Inc., Madison, WI.

Goff, D. A., R. Kullar, E. J. C. Goldstein, M. Gilchrist, D. Nathwani, A. C. Cheng, K. A. Cairns, K. Escandon-Vargas, M. V. Villegas, A. Brink, D. van den Bergh, and M. Mendelson. 2017. A global call from five countries to collaborate in antibiotic stewardship: United we succeed, divided we might fail. Lancet Infect. Dis. 17:e56-e63. https://doi.org/10.1016/s1473-3099(16)30386-3.

Gonggrijp, M. A., I. M. Santman-Berends, A. E. Heuvelink, G. J Buter, G. van Schaik, J. J. Hage, and T. J. Lam. 2016. Prevalence and risk factors for extended-spectrum beta-lactamase- and AmpC-producing Escherichia coli in dairy farms. J. Dairy Sci. 99:9001-9013. https://doi.org/10.3168/jds.2016-11134.

Green, M. J., A. J. Bradley, G. F. Medley, and W. J. Browne. 2007. Cow, farm, and management factors during the dry period that determine the rate of clinical mastitis after calving. J. Dairy Sci. 90:3764-3776. https://doi.org/10.3168/jds.2007-0107.

Green, M. J., A. J. Bradley, H. Newton, and W. J. Browne. 2006. Seasonal variation of bulk milk somatic cell counts in UK dairy herds: Investigations of the summer rise. Prev. Vet. Med. 74:293-308. https://doi.org/10.1016/j.prevetmed.2005.12.005.

Kiesner, K., N. Wente, O. Volling, and V. Kromker. 2016. Selection of cows for treatment at dry-off on organic dairy farms. J. Dairy Res. 83:468-475. https://doi.org/10.1017/S0022029916000662.

KNMvD. 2014. Guideline for the use of antimicrobials for drying of milking cows (in Dutch). Accessed Jun. 26, 2017. https://www .knmvd.nl/media/default.aspx/emma/org/10837091/richtlijn\%20 droogzetten\%20melkkoeien.pdf.

Kromker, V., N. T. Grabowski, and J. Friedrich. 2014. New infection rate of bovine mammary glands after application of an internal teat seal at dry-off. J. Dairy Res. 81:54-58. https://doi.org/10 .1017/S0022029913000599.

Middleton, J. R., A. Saeman, L. K. Fox, J. Lombard, J. S. Hogan, and K. L. Smith. 2014. The National Mastitis Council: A global organization for mastitis control and milk quality, 50 years and beyond. J. Mammary Gland Biol. Neoplasia 19:241-251. https://doi.org/ 10.1007/s10911-014-9328-6.

Mutze, K., W. Wolter, K. Failing, B. Kloppert, H. Bernhardt, and M. Zschock. 2012. The effect of dry cow antibiotic with and without an internal teat sealant on udder health during the first $100 \mathrm{~d}$ of lactation: a field study with matched pairs. J. Dairy Res. 79:477484. https://doi.org/10.1017/S0022029912000477.
OIE. 2016. The OIE strategy on antimicrobial resistance and the prudent use of antimicrobials. Accessed Jun. 26, 2017. http://www.oie .int/fileadmin/Home/eng/Media_Center/docs/pdf/PortailAMR/ EN_OIE-AMRstrategy.pdf.

Olde Riekerink, R. G., H. W. Barkema, and H. Stryhn. 2007. The effect of season on somatic cell count and the incidence of clinical mastitis. J. Dairy Sci. 90:1704-1715. https://doi.org/10.3168/jds $.2006-567$

Osteras, O., V. L. Edge, and S. W. Martin. 1999. Determinants of success or failure in the elimination of major mastitis pathogens in selective dry cow therapy. J. Dairy Sci. 82:1221-1231. https://doi .org/10.3168/jds.S0022-0302(99)75345-2.

Osteras, O., and L. Solverod. 2009. Norwegian mastitis control programme. Ir. Vet. J. 62(Suppl 4):S26-S33. https://doi.org/10.1186/ 2046-0481-62-S4-S26.

R Core Team. 2016. R: A language and environment for statistical computing. R Foundation for Statistical Computing, Vienna, Austria. https://www.R-project.org/.

Scherpenzeel, C. G., I. E. den Uijl, G. van Schaik, R. G. Riekerink, H. Hogeveen, and T. J. Lam. 2016a. Effect of different scenarios for selective dry-cow therapy on udder health, antimicrobial usage, and economics. J. Dairy Sci. 99:3753-3764. https://doi.org/ 10.3168/jds.2015-9963.

Scherpenzeel, C. G. M., S. H. W. Tijs, I. E. M. den Uijl, I. M. G. A. Santman-Berends, A. G. J. Velthuis, and T. J. G. M. Lam. 2016b. Farmers' attitude toward the introduction of selective dry cow therapy. J. Dairy Sci. 99:8259-8266. https://doi.org/10.3168/ jds.2016-11349.

Schukken, Y. H., D. J. Wilson, F. Welcome, L. Garrison-Tikofsky, and R. N. Gonzalez. 2003. Monitoring udder health and milk quality using somatic cell counts. Vet. Res. 34:579-596. https://doi.org/10 .1051/vetres:2003028.

SDa. 2014. Usage of antibiotics in agricultural livestock in the Netherlands in 2013. Accessed Jun. 26, 2017. http://www .autoriteitdiergeneesmiddelen.nl/Userfiles/AB\%20gebruik\%20 2013/sda-report-usage-of-antibiotics-2013-september-2014.pdf.

SDa. 2015. Usage of antibiotics in agricultural livestock in the Netherlands in 2014. Accessed Jun. 26, 2017. http://www .autoriteitdiergeneesmiddelen.nl/Userfiles/pdf/SDa-rapporten/ def-sda-rapport-ab-2014-engels-v2-aangepast-102015-incl-erratum .pdf.

SDa. 2016. Usage of antibiotics in agricultural livestock in the Netherlands in 2015. Accessed Jun. 26, 2017. http://www .autoriteitdiergeneesmiddelen.nl/Userfiles/Eng\%20rapport\%20 AB\%20gebruik\%202015/engels-rapportage-2015-geheel-rapport-13122016.pdf.

Sedgwick, P. 2015. Understanding the ecological fallacy. BMJ 351:h4773. https://doi.org/10.1136/bmj.h4773.

Speksnijder, D. C., D. J. Mevius, C. J. Bruschke, and J. A. Wagenaar. 2015. Reduction of veterinary antimicrobial use in the Netherlands. The Dutch success model. Zoonoses Public Health 62(Suppl 1):79-87. https://doi.org/10.1111/zph.12167.

Torres, A. H., P. J. Rajala-Schultz, F. J. Degraves, and K. H. Hoblet. 2008. Using dairy herd improvement records and clinical mastitis history to identify subclinical mastitis infections at dry-off. J. Dairy Res. 75:240-247. https://doi.org/10.1017/S0022029908003257.

van Hoeij, R. J., T. J. Lam, D. B. de Koning, W. Steeneveld, B. Kemp, and A. T. van Knegsel. 2016. Cow characteristics and their association with udder health after different dry period lengths. J. Dairy Sci. 99:8330-8340. https://doi.org/10.3168/jds.2016-10901.

Vissio, C., S. A. Dieser, H. L. Agnelli, L. M. Odierno, and A. J. Larriestra. 2014. Accuracy of the composite somatic cell count to detect intra-mammary infection in dairy cows using latent class analysis. Prev. Vet. Med. 113:547-555. https://doi.org/10.1016/j.prevetmed 2013.11.016.

WHO. 2015. Global action plan on antimicrobial resistance. Accessed Jun. 26, 2017. http://www.who.int/antimicrobial-resistance/ publications/global-action-plan/en/. 


\section{APPENDIX}

A flowchart explaining the guideline on the use of antimicrobials at dry-off in dairy cattle is shown in Figure A1.

The results from the mixed-effects logistic regression model could have been biased by the repeated effects of cows with multiple dry periods during the study $(51 \%$ of the dry periods were from cows with more than one dry period during the study). To accommodate this, a bootstrap approach was applied in $\mathrm{R}$ version 3.3.0 ( $\mathrm{R}$ Core Team, 2016).

We created 1,000 new data sets by randomly drawing a single dry period observation from each cow. All dry periods from cows with only 1 dry period during the study were by default in each data set. We applied a linear mixed-effects logistic regression with FSCC as the dependent variable $(0=$ greater than or equal to the threshold, 1 = less than the threshold; the threshold was $\geq 150,000$ cells $/ \mathrm{mL}$ for primiparous cows and $\geq 250,000$ cells $/ \mathrm{mL}$ for multiparous cows). As independent variables, we used DCT (no DCT, intramammary teat sealer and antimicrobial DCT, intramammary antimicrobial DCT only, or intramammary teat sealer only), LSCC ( $<$ the threshold or $\geq$ the threshold; the same thresholds as for FSCC were used), type of milking system (automatic or conventional), dry period length ( $\leq 30 \mathrm{~d}, 31-60 \mathrm{~d}$, or $>60 \mathrm{~d})$, parity at the moment of LSCC (primiparous or multiparous), and year of dry-off (2013, 2014, or 2015). Herd was added as a random effect to account for the correlation between the observations within a herd. The back-transformed variable estimates of the model of each data set were saved and the distribution of the results are visualized by boxplots for each variable (Figure A2). The estimates were summarized by obtaining percentiles (minimum, 0.025, median, 0.975, and maximum; Table A1). A total of 8 estimates from all of the models did not converge, so these estimates were excluded from the summary.

To explore the interaction between the LSCC and $\mathrm{DCT}$, an alternative mixed-effects logistic regression model analysis was carried out (Table A2). The final reduced alternative model was based on the lowest Akaike information criterion using a backward elimination approach. We applied the mixed-effects logistic regression model analysis in $\mathrm{R}$ version 3.3.0 ( $\mathrm{R}$ Core Team, 2016). In analogy to the initial model, we also applied a bootstrapped approach to avoid bias due to the repeated effects of cows with multiple dry periods within the study period (Table A3).

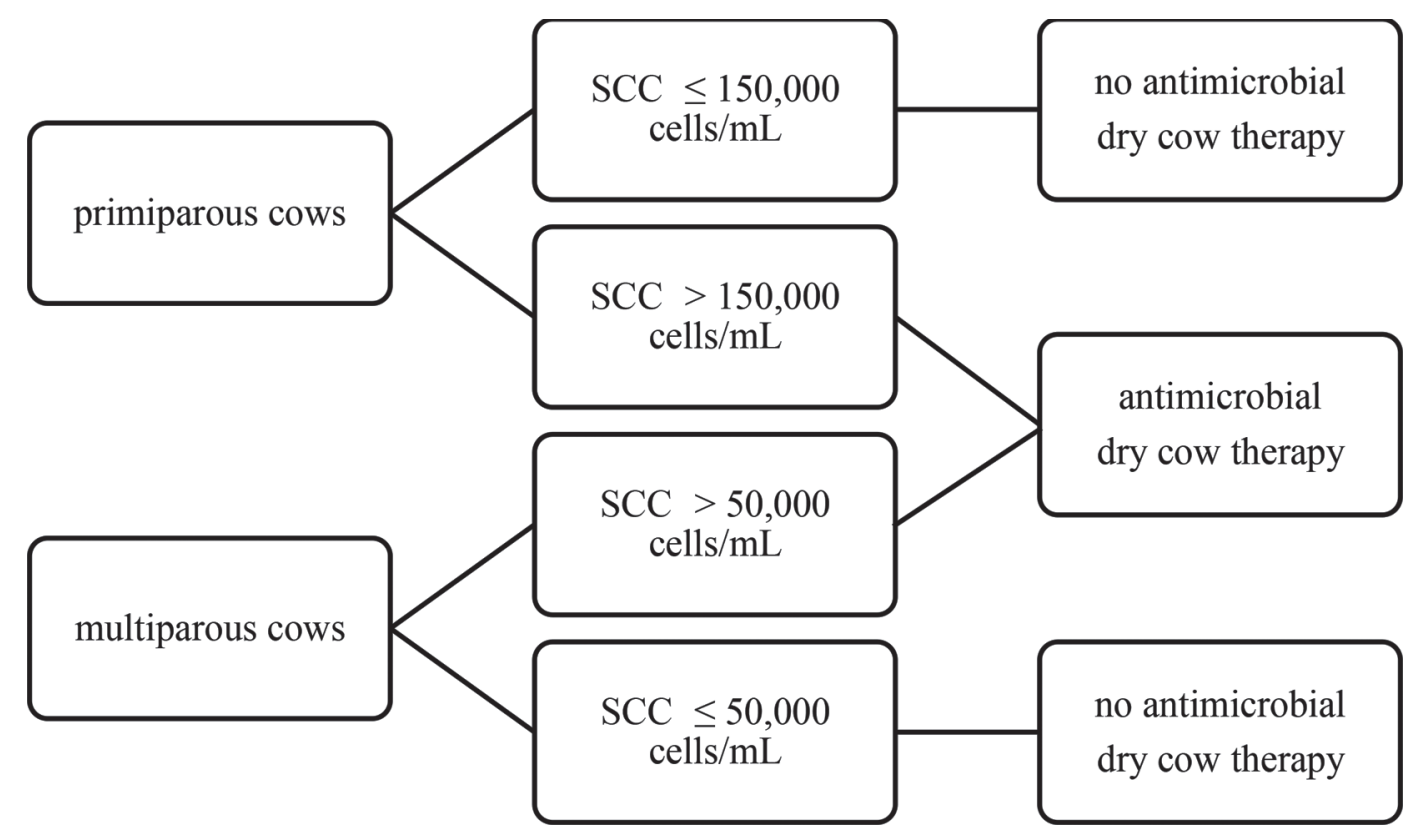

Figure A1. Flowchart explaining the guideline on the use of antimicrobials at dry-off in dairy cattle. Adapted from the Royal Dutch Veterinary Association (KNMvD, 2014). SCC $=$ the SCC of the last milk recording that occurred $\leq 6$ wk before dry-off. 


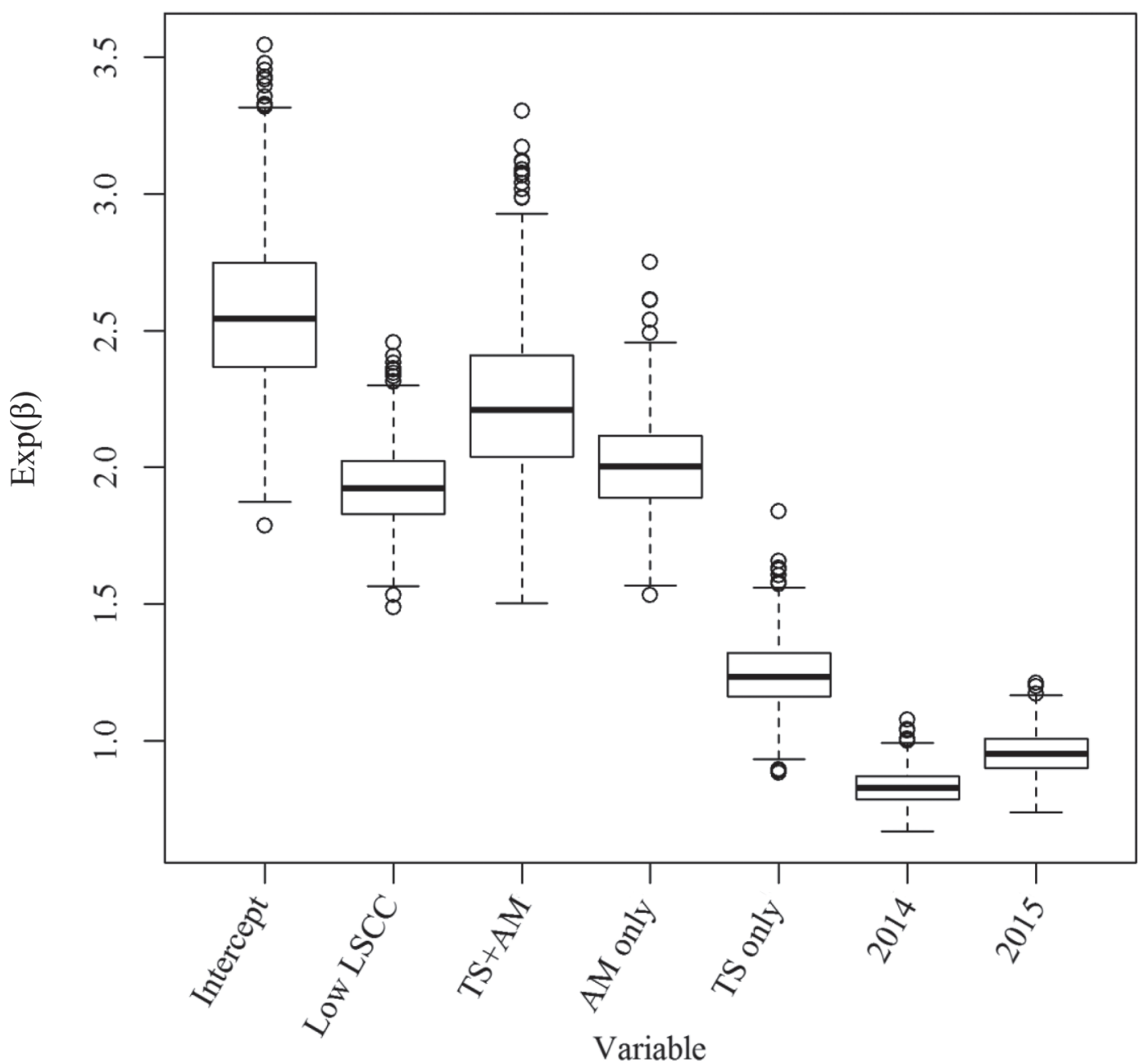

Figure A2. Boxplots of the estimates $[\operatorname{Exp}(\beta)]$ of the odds (intercept) and odds ratios for the variables of 1,000 data sets from the same linear mixed-effects model for observing a low SCC at the first milk recording following a dry period. The SCC threshold was $\geq 150,000$ cells/ $\mathrm{mL}$ for primiparous cows and $\geq 250,000$ cells $/ \mathrm{mL}$ for multiparous cows. The intercept is the odds of a low SCC at first milk recording following a dry period for a cow in the reference group (no dry cow therapy, high SCC at the last milk recording before dry-off, and dry-off in 2013). Boxes represent quartile 1 to 3, lines within the box represent the median, circles are observations deviating more than 1.5 times the box height $(\mathrm{IQR}=$ interquartile range) above quartile 3 or below quartile 1 , and the whiskers extend to the most extreme data point that is no more than 1.5 times the interquartile range from the box. LSCC = the SCC from the last milk recording before dry-off. A low LSCC was an SCC <the threshold. TS $+\mathrm{AM}=$ intramammary teat sealer and antimicrobial dry cow therapy. AM only = intramammary antimicrobial dry cow therapy only. TS only = intramammary teat sealer only. 2014 and 2015 indicate year of dry-off. 
Table A1. Summary (percentiles; P) of the variable estimates of 1,000 data sets ${ }^{1}$ by the same linear mixed-effects logistic regression model for the odds of a low $\mathrm{SCC}^{2}$ at the first milk recording following a dry period

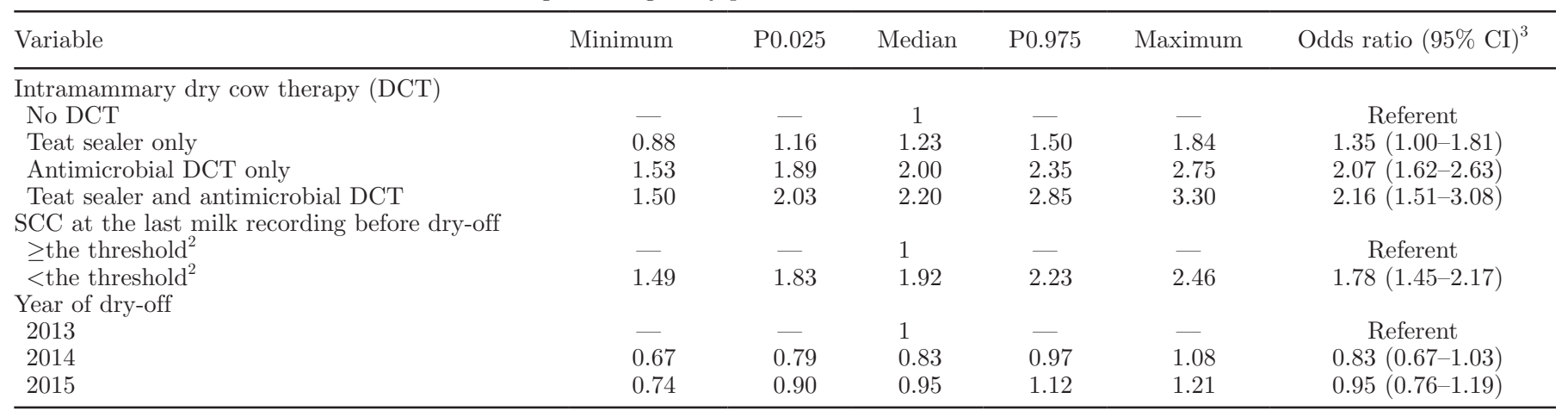

${ }^{1}$ Eight estimates from all the models did not converge and these estimates were excluded from the summary.

${ }^{2}$ The SCC threshold was $\geq 150,000$ cells $/ \mathrm{mL}$ for primiparous cows and $\geq 250,000$ cells $/ \mathrm{mL}$ for multiparous cows.

${ }^{3}$ Odds ratio estimates and $95 \%$ CI of the final reduced mixed-effects logistic regression model of the dry period SCC dynamics at individual dry period level ( $\mathrm{n}=20$ herds, 4,404 dry periods, and 2,638 cows).

Table A2. Results of the final reduced alternative mixed-effects logistic regression model ${ }^{1}$ of the dry period SCC dynamics at individual dry period level with the SCC of the first milk recording following a dry period as the dependent variable $(0=$ greater than or equal to the threshold, ${ }^{2} 1=$ less than the threshold $;^{2} \mathrm{n}=20$ herds, 4,404 dry periods, and 2,638 cows)

\begin{tabular}{|c|c|c|c|c|}
\hline Variable & Odds ratio & \multicolumn{2}{|c|}{$95 \% \mathrm{CI}$} & Odds ratio $(95 \% \mathrm{CI})^{3}$ \\
\hline \multicolumn{5}{|l|}{ LSCC $^{4} \times$ intramammary dry cow therapy $(\mathrm{DCT})$} \\
\hline No DCT & Referent & - & - & Referent \\
\hline Low LSCC $\times$ teat sealer only & 1.31 & 0.96 & 1.80 & $1.35(1.00-1.81)$ \\
\hline Low LSCC $\times$ antimicrobial DCT only & 2.01 & 1.52 & 2.67 & $2.07(1.62-2.63)$ \\
\hline High LSCC $\times$ antimicrobial DCT only & 2.18 & 1.34 & 3.55 & \\
\hline Low LSCC $\times$ teat sealer and antimicrobial DCT & 2.37 & 1.50 & 3.75 & $2.16(1.51-3.08)$ \\
\hline$<$ the threshold ${ }^{2}$ & 1.85 & 1.14 & 3.00 & $1.78(1.45-2.17)$ \\
\hline \multicolumn{5}{|l|}{ Year of dry-off ${ }^{5}$} \\
\hline 2013 & Referent & - & - & Referent \\
\hline 2014 & 0.83 & 0.67 & 1.03 & $0.83(0.67-1.03)$ \\
\hline 2015 & 0.95 & 0.77 & 1.19 & $0.95(0.76-1.19)$ \\
\hline
\end{tabular}

${ }^{1}$ Herd was used as a random effect to take the correlation between observations within a herd into account.

${ }^{2}$ The SCC threshold was equal to or greater than 150,000 cells $/ \mathrm{mL}$ for primiparous cows and equal to or greater than 250,000 cells $/ \mathrm{mL}$ for multiparous cows.

${ }^{3}$ Odds ratio estimates and $95 \%$ CI of the final reduced mixed-effects logistic regression model of the dry period SCC dynamics at individual dry period level ( $\mathrm{n}=20$ herds, 4,404 dry periods, and 2,638 cows).

${ }^{4} \mathrm{LSCC}=$ the SCC from the last milk recording before dry-off. A low LSCC was an SCC $<$ the threshold, ${ }^{2}$ and a high LSCC was an SCC $\geq$ the threshold. ${ }^{2}$

${ }^{5}$ The year of dry-off was fixed in the model because this study aimed to evaluate the change in dry period SCC dynamics over time. 
Table A3. Summary (percentiles; P) of the variable estimates of 1,000 data sets ${ }^{1}$ by the same alternative linear mixed-effects logistic regression model for the odds on a low $\mathrm{SCC}^{2}$ at the first milk recording following a dry period

\begin{tabular}{|c|c|c|c|c|c|c|}
\hline Variable & Minimum & P0.025 & Median & P0.975 & Maximum & Odds ratio $(95 \% \mathrm{CI})^{3}$ \\
\hline \multicolumn{7}{|l|}{$\overline{\text { LSCC }^{4} \times \text { intramammary dry cow therapy }(\mathrm{DCT})}$} \\
\hline No DCT & - & - & 1 & - & - & Referent \\
\hline High LSCC $\times$ teat sealer only & 0.50 & 0.95 & 1.13 & 1.88 & 2.58 & $1.58(0.78-3.21)$ \\
\hline Low LSCC $\times$ antimicrobial DCT only & 1.43 & 1.88 & 2.01 & 2.42 & 2.79 & $2.01(1.52-2.67)$ \\
\hline High LSCC $\times$ antimicrobial DCT only & 0.92 & 1.64 & 1.86 & 2.63 & 3.28 & $2.18(1.34-3.55)$ \\
\hline Low LSCC $\times$ teat sealer and antimicrobial DCT & 1.44 & 2.24 & 2.53 & 3.62 & 4.97 & $2.37(1.50-3.75)$ \\
\hline$\geq$ the threshold $^{2}$ & - & - & 1 & - & - & Referent \\
\hline$<$ the threshold $^{2}$ & 0.89 & 1.53 & 1.76 & 2.45 & 3.15 & $1.85(1.14-3.00)$ \\
\hline \multicolumn{7}{|l|}{ Year of dry-off } \\
\hline 2013 & - & - & 1 & - & - & Referent \\
\hline 2014 & 0.67 & 0.79 & 0.83 & 0.97 & 1.08 & $0.83(0.67-1.03)$ \\
\hline 2015 & 0.74 & 0.90 & 0.95 & 1.11 & 1.21 & $0.95(0.77-1.19)$ \\
\hline
\end{tabular}

${ }^{1}$ Eight estimates from all the models did not converge, and these estimates were excluded from the summary.

${ }^{2}$ The SCC threshold was $\geq 150,000$ cells $/ \mathrm{mL}$ for primiparous cows and $\geq 250,000$ cells $/ \mathrm{mL}$ for multiparous cows.

${ }^{3}$ Odds ratio estimates and $95 \%$ CI of the final reduced alternative mixed-effects logistic regression model of the dry period SCC dynamics at individual dry period level ( $\mathrm{n}=20$ herds, 4,404 dry periods, and 2,638 cows).

${ }^{4} \mathrm{LSCC}=$ the SCC from the last milk recording before dry-off. A low LSCC was an SCC $<$ the threshold ${ }^{2}$ and a high LSCC was an SCC $\geq$ the threshold. ${ }^{2}$ 